\title{
Synthesis and secretion of beeswax in honeybees
}

\author{
HR Hepburn 1*, RTF Bernard 1, BC Davidson 2, WJ Muller 1, \\ P Lloyd ${ }^{1}$, SP Kurstjens ${ }^{3}$, SL Vincent 1 \\ 1 Rhodes University, Department of Zoology and Entomology, Grahamstown 6140; \\ 2 University of the Witwatersrand, Department of Medical Biochemistry; \\ 3 University of the Witwatersrand, Department of Physiology, Johannesburg, 2193, South Africa
}

(Received 1 July 1990; accepted 15 November 1990)

\begin{abstract}
Summary - The ultrastructure of the cells of the wax gland complex in honeybee workers was studied in relation to the synthesis and secretion of beeswax. The hydrocarbon and fatty acid profiles of epidermal cells and oenocytes were determined in relation to the ages of the bees. Smooth endoplasmic reticulum (SER) is absent from both epidermis and adipocytes from adult emergence until the end of wax secretion. The oenocytes are rich in SER. The hydrocarbon and fatty acid content of the oenocytes, averaged for age, closely matches that of newly secreted wax. That the oenocytes are the probable source of the hydrocarbon fraction of beeswax is consistent with histochemical and autoradiographic data for honeybees and with biosynthetic data from other insects. The cyclical changes of organelles and chemical composition of the wax gland complex closely coincide with measured, age-related rates of wax secretion in honeybee workers.
\end{abstract}

wax secretion / wax synthesis / wax gland / ultrastructure / chemical composition

\section{INTRODUCTION}

Many tasks within the division of labour of worker honeybees are closely associated with age-related cycles of glandular activity (Ribbands, 1953; Winston, 1987). Histological studies of wax secretion suggest that production begins when the worker is slightly less than 1 wk old, peaks at $\approx 2$ wk and then wanes (Rösch, 1927; Freudenstein, 1960; Boehm, 1965; Hepburn et al, 1984). Of the tissues within the wax gland complex, the epidermis and the oenocytes in particular have been implicated as central to the synthesis and secretion of wax (Rösch, 1927; Reimann, 1952; Boehm, 1965).
Beeswax is a complex mixture (Tulloch, 1980) produced by tissues in the abdomen of the bee (Dumas and Edwards, 1843; Piek, 1961). The work of Piek (1961, 1964) showed that acetic acid is very probably taken up by the oenocytes and that acetate is used for the synthesis of hydrocarbons. This interpretation was strengthened by further studies of microsomal preparations from the worker abdomen (Blomquist and Ries, 1979; Lambremont and Wykle, 1979). Although the oenocytes may play a major role in the synthesis of wax, the synthetic capacity of individual cell types within the wax gland complex and their possible contribution to wax production have remained unexplored.

\footnotetext{
* Correspondence and reprints
} 
Searches for the means by which wax synthesized within the abdomen actually reaches the surface of the animal suggest that it passes through the pore canal system of the cuticle (Locke, 1961; Locke and Huie, 1980). Yet the means by which the precursors are transported from as yet unestablished points of origin has remained elusive. We conducted studies of wax synthesis and secretion in honeybees to specifically identify sites for the origin of hydrocarbon and fatty acids within the wax gland complex and to establish the necessary ultrastructural correlates of this activity and of their transport. Equally important, we measured the actual rates of wax secretion in bees of different ages to assess how well chemical composition of the tissues and cycles of ultrastructural change corresponded with the cycles of wax production within this stage of the division of labour.

\section{MATERIALS AND METHODS}

\section{Animals}

Newly emerged adult bees (Apis mellifera capensis) were marked by painting the thorax, placed in hives, and subsequently sampled at $\approx$ 72-h intervals over a 25-d period for use in subsequent microscopical and chemical studies.

\section{Light microscopy}

Bees were anaesthetized on ice and the fat body dissected out under saline (Miller and James, 1976). Fat bodies were stained for 2 $\mathrm{min}$ in $0.2 \%$ methylene blue and viewed on a cavity slide with a light microscope. The volumes of adipocytes and oenocytes were calculated from light microscope preparations. The diameters of 10 adipocytes and 10 oenocytes from each of 5 bees from each age group were measured with an ocular micrometer. The diam- eters were converted to volumes, assuming that the cells were spherical.

\section{Electron microscopy}

Bees were anaesthetized on ice, and fixative (2.5\% glutaraldehyde in $0.2 \mathrm{M}$ cacodylate buffer $(\mathrm{pH} 7.1)$ ) injected into the haemocoel (Locke and Huie, 1980). After $10 \mathrm{~min}$, the fat body and overlying epidermis were excised and further fixed by immersion in the above fixative for $4 \mathrm{~h}$ at room temperature. After primary fixation the tissues were washed in the buffer, secondarily fixed in $1.0 \%$ buffered osmium tetroxide, dehydrated and embedded in a Taab/Araldite resin mixture. Ultrathin sections (silver/gold) were stained with uranyl acetate (Watson, 1958) and lead citrate (Reynolds, 1963) and examined using a Jeol JEMXII transmission electron microscope.

Volume densities (volume of the component related to the volume of the containing cell) of the wax gland organelles were calculated using the point count method (Weibel and Bolender, 1973). A grid of 99 squares, each $9 \mathrm{~mm}^{2}$, was drawn on the screen of the electron microscope onto which the image (29 000X) of the tissue was superimposed. At least 10 oenocytes and 10 adipocytes from 3 wax glands per age group were used for the point count analysis.

\section{Chemical analyses}

Wax gland cells used for fatty acid and hydrocarbon analysis were harvested as follows. Live bees were flash-frozen in liquid nitrogen and stored at $-70^{\circ} \mathrm{C}$ until processed. Tissue was obtained after thawing by dissection of the abdomen in a phosphate buffered saline solution. Deep freezing followed by saline rehydration at room temperature caused only the adipocytes to burst. The remaining intact oenocytes in the former fat body layer were collected with a micropipette and the purity of the cell type (exclusion of adipocytes) confirmed by microscopy. After removal of the inner tissues, only those epidermal cells underlaying wax mirrors were scraped free and similarly harvested. Epidermal cells and oenocytes were separately spun at $200 \mathrm{~g}$ for $\mathbf{1 5}$ min to obtain pellets. 
The cell pellets were extracted with chloroform:methanol $(2: 1 \mathrm{v} / \mathrm{v})$, the extracts washed with saline $(0.9 \%)$ and reduced under vacuum (Floch et al, 1957). Half of each sample was used for hydrocarbon analysis and the remainder used to prepare fatty acid esters (FAME) using the method of Moscatelli (1972). The FAME were separated using a $10 \%$ SP2330 $6 \mathrm{~m} \times$ $3 \mathrm{~mm}$ ID column in a Varian $3400 \mathrm{GC}$ and were quantitated using a Varian 4270 integrator. The hydrocarbons were separated using a $2 \mathrm{~m} \times 0.2$ $\mathrm{mm}$ ID QVI column with the same GC/integrator system. Samples of scale and comb wax were extracted in parallel with the cell samples and processed in the same way.

\section{Wax secretion}

Wax secretion was measured in worker bees from queenright colonies of $\approx 10000$ bees hived in 5-framed nuclei, 3 frames of which contained brood and food stores. The bees were heavily fed sugar syrup (25-50 g sucrose/l water) ad libitum to stimulate comb building. Newly emerged bees were marked for age and introduced at the rate of 150 bees/hive every $3 d$ into each of 7 colonies. On d 21 the colonies contained a spectrum of age groups that were $3,6,9,12,15,18$ and $21 \mathrm{~d}$ old. All of these bees were then harvested and their wax scales removed and weighed on a Cahn C-32 microbalance. Such measurements were made over $2 \mathrm{yr}$ and very large samples of each age group were eventually obtained as follows. Bee group age is followed by sample size for that age in parentheses : 3 (1360), 6 (1543), 9 (1635), 12 (2003), 15 (1973), 18 (1552), and 21 (1230).

\section{RESULTS}

\section{Ultrastructure}

The epidermis of the wax mirror is underlain by a fat body layer, comprising oenocytes and adipocytes (figs 1,2 ). In the oenocytes of the newly emerged worker bee SER is barely discernible, but by the fourth day the volume density of these tightly packed tubules is high (table I). Similarly, there is a large increase in whole oenocyte volume (table I) as previously noted by Boehm (1965). The relative volumes of the oenocytes and the SER remain elevated throughout the secretory phase (table I, fig 3). By d 18, both oenocytes and SER begin to decrease (table I) with the simultaneous appearance of primary lysosomes and autolytic vacuoles. Lipid and protein droplets were never observed in the oenocytes and other cellular organelles showed no evident cyclical changes associated with wax synthesis (table I).

The adipocytes are characterized by an extensive plasma membrane reticular system, numerous mitochondria, peroxisomes and RER, and a few small Golgi bodies (fig 4). SER is notably absent from adult emergence through foraging. Massive lipid droplets occupy $\approx 60 \%$ of cell's cytoplasm in the young worker but decrease substantially over the next few days (table II). Like

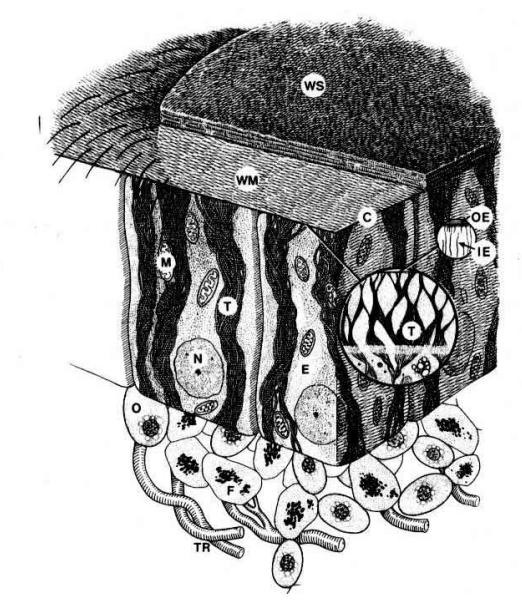

Fig 1. Diagram of the honeybee wax gland complex. WS $=$ wax scale, $W M$ and $C=$ wax mirror cuticle, OE = outer epicuticle, IE = inner epicuticle, $\mathrm{T}=$ wax tubules, $\mathrm{E}=$ epidermal cell, $\mathrm{N}=$ nucleus, $\mathrm{M}=$ mitochondria, $\mathrm{O}=$ oenocytes, $\mathrm{F}=$ adipocytes and TR $=$ tracheole (from Hepburn, 1986). 


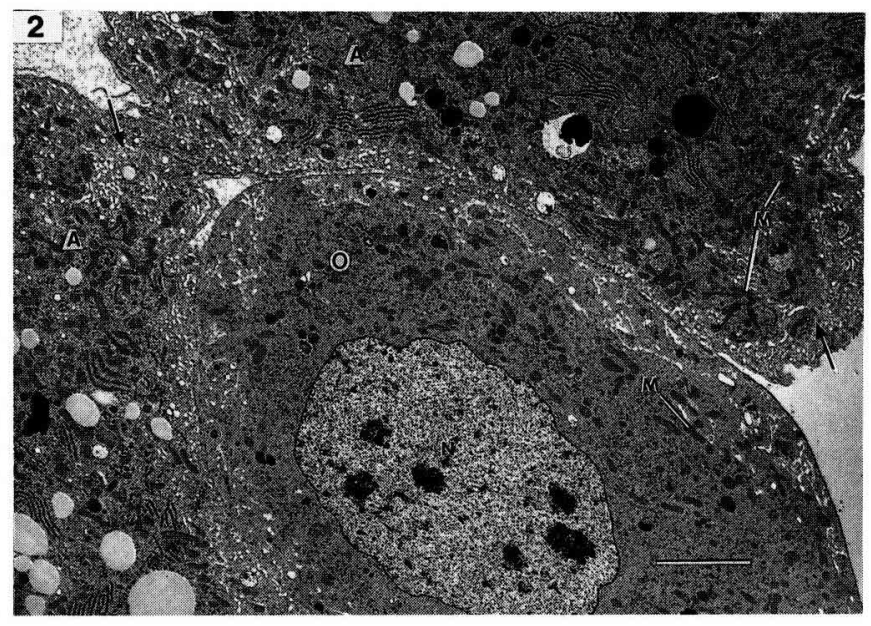

Fig 2. Part of a fat body from a 12-d-old bee at the peak of wax secretion showing the typical appearance of an oenocyte (0) with 2 adjacent adipocytes $(A) . M=$ mitochondria, $N=$ nucleus, arrows indicate the plasma membrane reticular system. Scale bar $=4 \mu \mathrm{m}$.

the oenocytes, the adipocytes also increase in volume prior to wax synthesis (table II). During wax synthesis, glycogen stores are notably large and the plasma membrane reticular system is well developed. As synthesis wanes, lipid droplets in-

Table I. Volume changes in the wax gland oenocytes of the Cape worker honeybee with age.

\begin{tabular}{|c|c|c|c|c|c|c|c|c|c|}
\hline \multirow{2}{*}{ Feature } & \multicolumn{9}{|c|}{ Bee age (d) } \\
\hline & 0 & 4 & 6 & 9 & 12 & 14 & 16 & 18 & 21 \\
\hline $\begin{array}{l}\text { Whole } \\
\text { cella }\end{array}$ & $8 \pm 4$ & $36 \pm 13$ & $54 \pm 16$ & $39 \pm 10$ & $45 \pm 13$ & $40 \pm 14$ & $52 \pm 22$ & $32 \pm 10$ & $30 \pm 12$ \\
\hline$S E R^{b}$ & $65 \pm 10$ & $83 \pm 14$ & $82+6$ & $83 \pm 24$ & $81 \pm 9$ & $82 \pm 10$ & $8 \pm 12$ & $85 \pm 12$ & $74 \pm 15$ \\
\hline Mitochondriab & 10 & 9 & 8 & 8 & 8 & 9 & 7 & 5 & 7 \\
\hline $\begin{array}{l}\text { Glycogen } \\
\text { granules }\end{array}$ & 23 & 7 & 8 & 9 & 9 & 7 & 6 & 7 & 15 \\
\hline
\end{tabular}

a Oenocyte volume $\left(x 1000 \mu \mathrm{m}^{3}\right)$. Bees of age 0,4 and $6 \mathrm{~d}$ were significantly different $(P<0.05)$ from each other and from the groups 9-18-d-old, but there were no significant differences within the 9-18-d-old group. Similarly, bees of 18 and $21 \mathrm{~d}$ were not significantly different from each other but were different $(P<0.05)$ from the 9-18-d-old groups. ${ }^{b}$ Organelle volume density expressed as a percentage of mean oenocyte cytoplasmic volume occupied by organelle. For SER, bees of age 0 and $21 \mathrm{~d}$ were significantly different $(P<0.05)$ from ages $4-18 \mathrm{~d}$. There were no significant differences between any of the 4-18-d-old groups. 


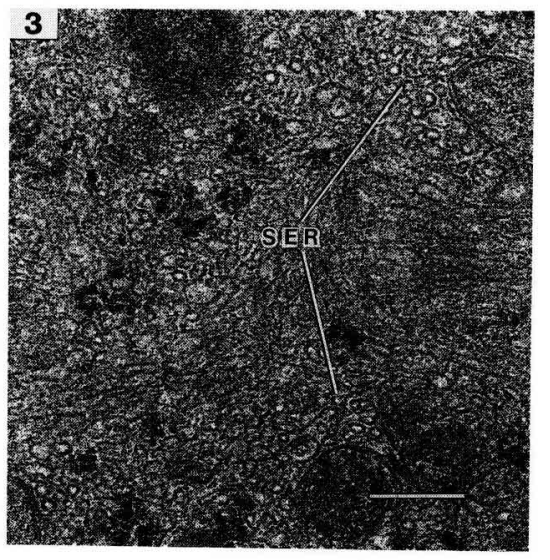

Fig 3. Representative section of the cytoplasm of an oenocyte from a 12-d-old bee illustrating the abundance and form of the smooth endoplasmic reticulum (SER). Scale bar : $0.25 \mu \mathrm{m}$.

crease in size while the other organelles either remain unchanged or show small decreases in size (table II).

Within the fat body adjacent adipocytes are separated by a gap of $\approx 250 \mathrm{~nm}$ which is filled with material of the basal lamina (fig 5). There are many hemidesmosomes between each adipocyte and its basal lamina (fig 5). In places where adjacent adipocytes are $<50 \mathrm{~nm}$ apart, they are joined by desmosomes and gap junctions (fig 5 insert). The basal laminae of neighbouring oenocytes are separated by a gap of $\approx 150$ $\mathrm{nm}$, and like the adipocytes, are attached to their basal laminae by hemidesmosomes. No junctions were seen to link any 2 oenocytes. Similarly, where oenocyte abuts adipocyte, only hemidesmosomes are present (figs 6,7 ). The gap between adipocyte and oenocyte is $\approx 210 \mathrm{~nm}$. Although the cells of the fat body become closely applied to the basal lamina of the epidermis, particularly during the period of synthesis and secretion (cf Hepburn, 1986), the epidermal cells and cells of the fat body are not bound together by any form of junction but remain separated by their basal laminae.

\section{Hydrocarbons and fatty acids}

The hydrocarbons and fatty acids of the epidermis and oenocytes were analyzed in

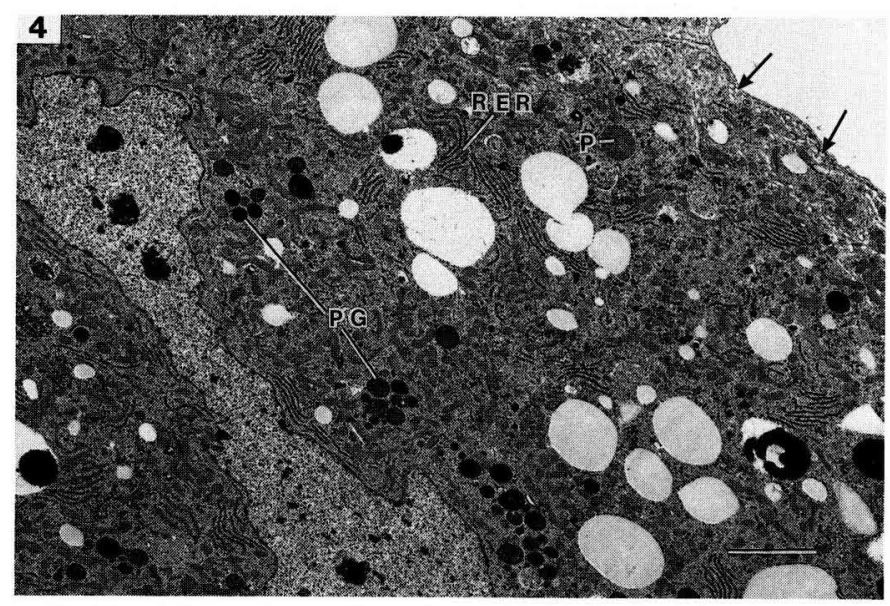

Fig 4. Part of an adipocyte from a 6-d-old bee showing the protein granules (PG), rough endoplasmic reticulum (RER), and complex plasma membrane reticular system (arrows) which characterise adipocytes at this time. $P=$ peroxisome. Scale bar $=4 \mu \mathrm{m}$. 
Table II. Volume changes in the wax gland adipocytes of the Cape worker honeybee with age.

\begin{tabular}{|c|c|c|c|c|c|c|c|c|c|}
\hline \multirow[t]{2}{*}{ Feature } & \multicolumn{9}{|c|}{ Bee age (d) } \\
\hline & 0 & 4 & 6 & 9 & 12 & 14 & 16 & 18 & 21 \\
\hline $\begin{array}{l}\text { Whole } \\
\text { cella }\end{array}$ & $65 \pm 26$ & $110 \pm 52$ & $130 \pm 100$ & $117 \pm 48$ & $123 \pm 52$ & $120 \pm 87$ & $143 \pm 65$ & $95 \pm 37$ & $97 \pm 32$ \\
\hline $\mathrm{RER}^{b}$ & 2 & 8 & 5 & 4 & 4 & 3 & 3 & 2 & 2 \\
\hline Mitochondriab & 5 & 10 & 8 & 8 & 10 & 9 & 11 & 12 & 13 \\
\hline $\begin{array}{l}\text { Lipid } \\
\text { droplets }\end{array}$ & 61 & 24 & 22 & 21 & 17 & 25 & 18 & 17 & 21 \\
\hline $\begin{array}{l}\text { Protein } \\
\text { granules }^{b}\end{array}$ & - & 10 & 19 & 22 & 7 & 1 & 6 & - & - \\
\hline $\begin{array}{l}\text { Glycogenb } \\
\text { granules }\end{array}$ & 5 & 3 & 14 & 6 & 10 & 5 & 7 & 10 & 7 \\
\hline
\end{tabular}

a Adipocyte vol $(x \uparrow 000 \mu \mathrm{m} 3)$. Bees of age $0 \mathrm{~d}$ were significantly different $(P<0.05)$ from those of 4-16-d groups but there were no differences within the 4-16-d-old groups. Similarly, bees of 18 and 21 -d-old were not different from each other, but both were significantly different $(P<0.05)$ from the 4-16-d-old groups.

bees of the same ages as those used in dominated by the $\mathrm{C}_{25}$ and $\mathrm{C}_{27}$ groups, and the ultrastructural studies. There was an a decrease in the $\mathrm{C}_{33}$ fraction of the oeincrease in the saturated hydrocarbons nocytes in relation to age (table III). The

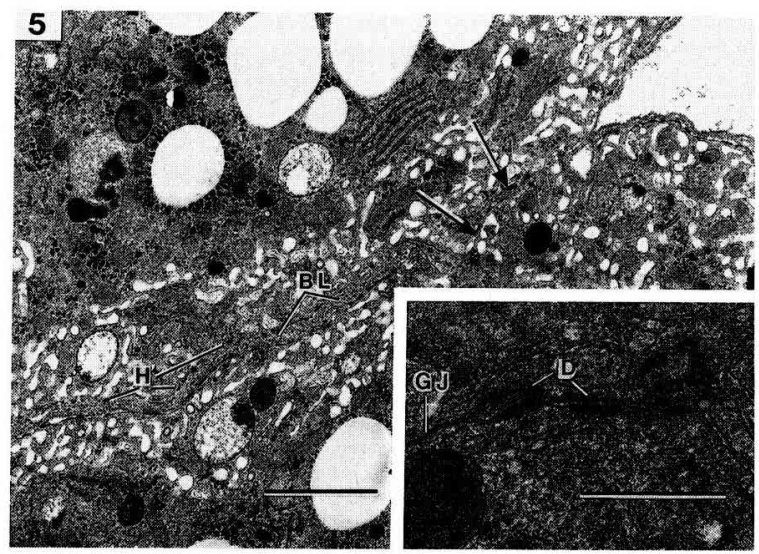

Fig 5. Two adjacent adipocytes of a 12-d-old bee separated by a gap filled with material of the basal lamina (BL). Hemidesmosomes (H) connect each adipocyte to its basal lamina. Arrows indicate a region in which the adipocytes are bound together more closely. Scale bar $=2.0 \mu \mathrm{m}$. Insert. Detail of the junctional complex from the area indicated by arrows. Two adipocytes are bound together by desmosomes (D) and gap junctions (GJ). Scale bar $=0.5 \mu \mathrm{m}$. 


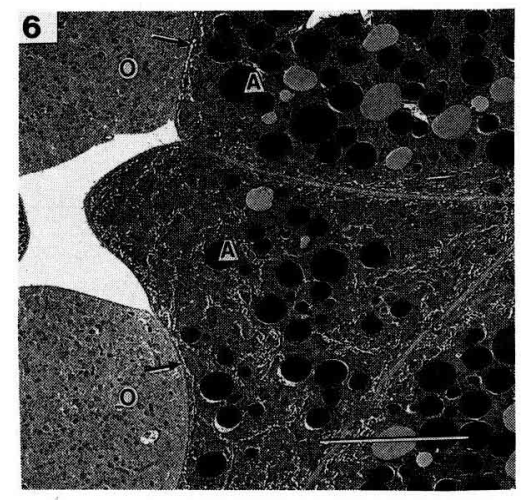

Fig 6. Part of a fat body of a 12-d-old bee showing the separation (arrows) of oenocyte $(O)$ from adjacent adipocyte (A). Scale bar $10 \mu \mathrm{m}$.

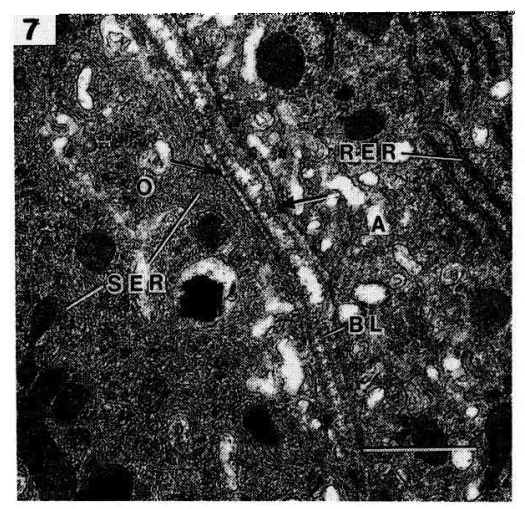

Fig 7. Detail of the region of apposition of an adipocyte (A) and oenocyte (O) in a 12-d-old bee. The space between the 2 cells is filled with material from the basal lamina (BL). Hemidesmosomes (arrows) retain the relationships between each cell and its basal lamina. Note SER of the oenocyte and RER of the adipocyte. Scale bar = $1 \mu \mathrm{m}$.

saturated groups increased at the expense of the unsaturated groups, particularly in the case of 33:1. The trends for the epidermal cells are similar, but on a smaller scale (table IV). Notable differences include an increase in the $\mathrm{C}_{29}$ pool while $\mathrm{C}_{25}$ and $\mathrm{C}_{27}$ remained about the same. Among the unsaturated groups there was a marked reduction in $35: 1$ in the epidermis in relation to age (table IV).

The fatty acid profiles of the oenocytes and epidermal cells in relation to age are given in tables $V$ and $V I$ respectively. While the total pool of saturated fatty acids in the oenocytes remained much the same there were notable increases in 12:0 and decreases in 16:0 and 24:0 in relation to age (table V). Only minor changes occurred in the unsaturated fatty acid pool. The epidermal cells showed even fewer changes in fatty acid composition in relationship to age (table VI).

Values for scale wax are based on samples of scales that were harvested over several years in other age-related experiments. Thus, these values represent the already averaged content of thousands of individual scales taken from as many bees between 3 and $21 \mathrm{~d}$ of age. (An internal control run established no differences between samples of scale wax that were freshly secreted or were 2 yr old.) Because of the necessity to pool wax scale samples, the data of tables III to VI are reexpressed as total averages for direct comparison with scale wax in tables VII and VIII. The former provide insight into the metabolic activities of the wax gland tissues on an age-related basis, the latter allow comparisons of average product content.

In the case of hydrocarbons, the average content of scale wax shows a $50 \%$ reduction in the saturated $\mathrm{C}_{25}$ group compared with the 2 wax gland tissues (table VII). Also, the $\mathrm{C}_{33}$ hydrocarbons of the oenocytes are far less than those of either epidermis or scale wax. The other hydrocarbons are much the same for tissue and scale wax (table VII). In the case of the fat- 
Table III. Changes in the percentage composition of hydrocarbons in the wax gland oenocytes of the Cape honeybee worker with age.

\begin{tabular}{|c|c|c|c|c|c|c|c|c|}
\hline Hydrocarbon & 0 & 3 & 6 & $\begin{array}{c}\text { Bee a } \\
\quad 9\end{array}$ & 12 & 15 & 18 & 21 \\
\hline $\begin{array}{l}25: 0 \\
27: 0\end{array}$ & $\begin{array}{l}23.8 \\
38.8\end{array}$ & $\begin{array}{l}23.0 \\
37.2\end{array}$ & $\begin{array}{l}21.9 \\
35.8\end{array}$ & $\begin{array}{l}26.9 \\
36.1\end{array}$ & $\begin{array}{l}26.6 \\
40.7\end{array}$ & $\begin{array}{l}30.0 \\
44.0\end{array}$ & $\begin{array}{l}29.9 \\
47.8\end{array}$ & $\begin{array}{l}31.0 \\
51.7\end{array}$ \\
\hline 29:0 & 4.5 & 6.4 & 7.5 & 12.0 & 9.7 & 8.0 & 6.3 & 2.0 \\
\hline $31: 0$ & 3.0 & 2.6 & 2.8 & 2.8 & 3.5 & 2.0 & 3.0 & 3.4 \\
\hline $33: 0$ & 6.0 & 6.4 & 4.7 & 4.6 & 5.3 & 4.0 & 4.5 & 3.4 \\
\hline $35: 0$ & 1.5 & 1.3 & 0.9 & 0.9 & 1.8 & 2.0 & 3.0 & 1.7 \\
\hline $\begin{array}{l}\text { Total } \\
31: 1\end{array}$ & $\begin{array}{r}77.6 \\
4.5\end{array}$ & $\begin{array}{r}76.9 \\
6.4\end{array}$ & $\begin{array}{r}73.6 \\
8.5\end{array}$ & $\begin{array}{r}83.3 \\
6.5\end{array}$ & $\begin{array}{r}87.6 \\
5.3\end{array}$ & $\begin{array}{r}90.0 \\
4.0\end{array}$ & $\begin{array}{r}92.5 \\
4.5\end{array}$ & $\begin{array}{r}93.2 \\
3.4\end{array}$ \\
\hline $33: 1$ & 17.9 & 16.7 & 17.9 & 10.2 & 7.1 & 6.0 & 3.0 & 3.4 \\
\hline Total & 22.4 & 23.1 & 26.4 & 16.7 & 12.4 & 10.0 & 7.5 & 6.8 \\
\hline
\end{tabular}

ty acids, there are large differences between the short chain groups $\left(\mathrm{C}_{12}\right.$ and $\mathrm{C}_{14}$ ) and the long ones $\left(\mathrm{C}_{24}-\mathrm{C}_{28}\right)$ for the tissues and the scale wax. There are also notable differences between tissue and scale wax among the unsaturated fatty acids (table VIII).

\section{Wax secretion}

The amounts of wax borne on average by worker bees of different ages are shown in figure 8. Paired comparisons of different age groups showed that not all age groups differed significantly. It is nonetheless

Table IV. Changes in the percentage composition of hydrocarbons in the wax gland epidermis of the Cape honeybee worker with age.

\begin{tabular}{|c|c|c|c|c|c|c|c|c|}
\hline \multirow[b]{2}{*}{ Hydrocarbon } & \multirow[b]{2}{*}{0} & \multirow[b]{2}{*}{3} & \multirow[b]{2}{*}{6} & \multicolumn{2}{|c|}{ Bee age (d) } & \multirow[b]{2}{*}{15} & \multirow[b]{2}{*}{18} & \multirow[b]{2}{*}{21} \\
\hline & & & & 9 & 12 & & & \\
\hline $25: 0$ & 20.6 & 22.3 & 21.9 & 21.3 & 21.6 & 24.0 & 23.2 & 22.5 \\
\hline $27: 0$ & 39.7 & 37.0 & 33.3 & 35.0 & 33.6 & 37.4 & 37.8 & 43.7 \\
\hline $29: 0$ & 6.9 & 7.4 & 8.3 & 9.7 & 8.4 & 10.4 & 12.2 & 9.9 \\
\hline $31: 0$ & 4.4 & 2.5 & 3.1 & 3.9 & 3.7 & 2.1 & 3.7 & 4.2 \\
\hline $33: 0$ & 10.3 & 11.1 & 12.5 & 14.6 & 15.9 & 12.5 & 13.4 & 12.7 \\
\hline $35: 0$ & 2.9 & 3.7 & 2.1 & 1.9 & 3.7 & 3.1 & 2.4 & 2.8 \\
\hline Total & 83.8 & 84.0 & 81.2 & 86.4 & 86.9 & 89.5 & 92.7 & 95.8 \\
\hline $33: 1$ & 4.4 & 3.7 & 6.3 & 5.8 & 5.6 & 4.2 & 2.4 & 1.4 \\
\hline $35: 1$ & 11.8 & 12.3 & 12.5 & 7.8 & 7.5 & 6.3 & 4.9 & 2.8 \\
\hline Total & 16.2 & 16.0 & 18.8 & 13.6 & 13.1 & 10.5 & 7.3 & 4.2 \\
\hline
\end{tabular}


Table V. Changes in the percentage composition of fatty acids in the wax gland oenocytes of the Cape honeybee worker with age.

\begin{tabular}{|c|c|c|c|c|c|c|c|c|}
\hline \multirow[t]{2}{*}{ Fatty acid } & \multicolumn{8}{|c|}{ Bee age (d) } \\
\hline & 0 & 3 & 6 & 9 & 12 & 15 & 18 & 21 \\
\hline $12: 0$ & 0.0 & 0.0 & 0.0 & 0.0 & 3.1 & 7.0 & 14.1 & 28.8 \\
\hline $14: 0$ & 4.4 & 4.6 & 4.8 & 3.9 & 4.2 & 3.5 & 2.5 & 2.5 \\
\hline $16: 0$ & 19.3 & 17.6 & 15.0 & 14.7 & 14.5 & 12.0 & 10.9 & 8.4 \\
\hline $18: 0$ & 4.1 & 3.9 & 4.1 & 4.4 & 4.7 & 4.8 & 5.2 & 4.4 \\
\hline $20: 0$ & 2.2 & 1.9 & 1.7 & 1.9 & 1.8 & 1.9 & 1.8 & 1.7 \\
\hline $22: 0$ & 1.2 & 1.1 & 1.2 & 1.6 & 1.8 & 2.0 & 2.2 & 1.9 \\
\hline $24: 0$ & 48.5 & 48.9 & 50.8 & 50.9 & 54.3 & 49.2 & 45.2 & 34.8 \\
\hline $26: 0$ & 0.0 & 0.0 & 0.0 & 0.0 & 0.0 & 0.0 & 0.0 & 0.0 \\
\hline $28: 0$ & 0.0 & 0.0 & 0.0 & 0.0 & 0.0 & 0.0 & 0.0 & 0.0 \\
\hline Total & 79.7 & 77.0 & 77.6 & 77.4 & $\cdot 79.4$ & 80.4 & 81.9 & 82.5 \\
\hline $16: 1 \mathrm{n} 9$ & 2.3 & 3.7 & 4.7 & 4.6 & 3.9 & 3.2 & 3.0 & 2.8 \\
\hline $18: 1 n 9$ & 4.5 & 5.4 & 5.3 & 5.5 & 6.0 & 4.9 & 3.6 & 3.9 \\
\hline $20: 1 n 9$ & 1.5 & 1.9 & 1.4 & 1.5 & 1.1 & 1.0 & 1.0 & 0.9 \\
\hline Total & 8.3 & 11.0 & 11.5 & 11.6 & 11.0 & 9.1 & 7.6 & 7.6 \\
\hline $18: 2 n 6$ & 7.4 & 6.7 & 6.6 & 6.6 & 6.8 & 6.7 & 6.6 & 6.3 \\
\hline $18: 3 n 6$ & 2.0 & 1.5 & 1.3 & 1.3 & 1.4 & 1.3 & 1.4 & 1.4 \\
\hline $20: 4 n 6$ & 1.2 & 1.3 & 1.2 & 1.1 & 1.2 & 1.1 & 1.1 & 0.9 \\
\hline Total & 10.6 & 9.5 & 9.1 & 9.0 & 9.4 & 9.1 & 9.1 & 8.6 \\
\hline $18: 3 n 3$ & 1.0 & 1.3 & 1.6 & 1.7 & 1.1 & 1.0 & 1.2 & 1.0 \\
\hline $20: 5 n 3$ & 0.4 & 0.4 & 0.4 & 0.5 & 0.4 & 0.3 & 0.4 & 0.4 \\
\hline Total & 1.4 & 1.7 & 2.0 & 2.2 & 1.5 & 1.3 & 1.6 & 1.4 \\
\hline
\end{tabular}

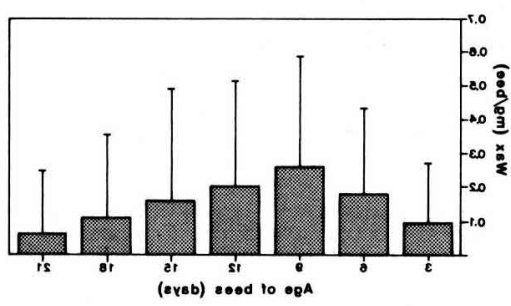

Fig 8. Wax secretion $(\mathrm{mg})$ by individual worker honeybees of different ages. Values given as mean and standard deviation. Sample sizes are given in the Methods section.

worth commenting on the magnitude of the standard deviation. It requires between 24 and $48 \mathrm{~h}$ for any particular honeybee worker to produce a moderate-sized wax scale
(Hepburn and Muller, 1988). Moreover, on harvest, one cannot tell whether an individual honeybee with no or only little wax on it is in this state because it either did not secrete any wax or had recently removed its scales and added them to the combbuilding in progress. Consequently, one cannot relate any specific amount of wax back to a defined zero time. However, the general trend of the data is highly significant and fully supported by the one-way analysis of variance. Thus, the amount of wax borne per bee is significantly $(P<$ 0.05 ) affected by the age class of the bee.

\section{DISCUSSION}

When the adult worker bee emerges from its cell the cuticle of the wax mirror is $\approx 3$ 
Table VI. Changes in the percentage composition of fatty acids of the wax gland epidermis of the Cape honeybee worker with age.

\begin{tabular}{|c|c|c|c|c|c|c|c|c|}
\hline \multirow[b]{2}{*}{ Fatty acid } & \multirow[b]{2}{*}{0} & \multirow[b]{2}{*}{3} & \multicolumn{3}{|c|}{ Bee age (d) } & \multirow[b]{2}{*}{15} & \multirow[b]{2}{*}{18} & \multirow[b]{2}{*}{21} \\
\hline & & & 6 & 9 & 12 & & & \\
\hline $12: 0$ & 0.0 & 0.0 & 0.0 & 0.0 & 0.0 & 0.0 & 0.0 & 0.0 \\
\hline $14: 0$ & 2.5 & 2.5 & 2.9 & 3.1 & 2.8 & 2.9 & 2.8 & 2.7 \\
\hline $16: 0$ & 26.5 & 23.8 & 25.9 & 24.7 & 26.2 & 25.6 & 25.9 & 25.3 \\
\hline $18: 0$ & 10.0 & 7.0 & 5.5 & 4.6 & 3.3 & 3.9 & 3.7 & 7.6 \\
\hline $20: 0$ & 0.3 & 0.3 & 0.2 & 0.3 & 0.3 & 0.4 & 0.3 & 0.2 \\
\hline $22: 0$ & 0.6 & 0.6 & 0.6 & 0.6 & 0.4 & 0.3 & 0.4 & 0.2 \\
\hline $24: 0$ & 21.5 & 25.8 & 24.4 & 27.2 & 25.0 & 20.4 & 23.5 & 22.5 \\
\hline $26: 0$ & 0.0 & 0.0 & 0.0 & 0.0 & 0.0 & 0.0 & 0.0 & 0.0 \\
\hline $28: 0$ & 0.0 & 0.0 & 0.0 & 0.0 & 0.0 & 0.0 & 0.0 & 0.0 \\
\hline Total & 61.4 & 59.9 & 59.6 & 60.4 & 58.1 & 53.5 & 56.7 & 58.5 \\
\hline $16: 1 \mathrm{n} 9$ & 2.4 & 2.4 & 2.1 & 2.2 & 2.3 & 2.1 & 1.9 & 2.0 \\
\hline $18: 1 \mathrm{ng}$ & 8.0 & 7.7 & 7.7 & 8.4 & 9.5 & 9.0 & 8.5 & 8.1 \\
\hline $20: 1 \mathrm{n} 9$ & 2.4 & 2.4 & 2.6 & 2.5 & 2.6 & 2.9 & 2.7 & 2.6 \\
\hline Total & 12.8 & 12.6 & 12.4 & 13.1 & 14.3 & 14.0 & 13.1 & 12.8 \\
\hline $18: 2 n 6$ & 18.1 & 16.7 & 17.7 & 16.2 & 19.3 & 22.9 & 21.0 & 20.7 \\
\hline $18: 3 n 6$ & 0.6 & 0.6 & 0.3 & 0.3 & 0.3 & 0.4 & 0.4 & 0.4 \\
\hline $20: 4 n 6$ & 6.8 & 9.9 & 9.9 & 8.1 & 7.6 & 8.8 & 8.4 & 7.4 \\
\hline Total & 25.4 & 27.2 & 27.8 & 26.6 & 27.2 & 32.1 & 29.8 & 28.5 \\
\hline $18: 3 n 3$ & 0.3 & 0.3 & 0.2 & 0.4 & 0.4 & 0.4 & 0.5 & 0.3 \\
\hline $20: 5 n 3$ & 0.0 & 0.0 & 0.0 & 0.0 & 0.0 & 0.0 & 0.0 & 0.0 \\
\hline Total & 0.3 & 0.3 & 0.2 & 0.4 & 0.4 & 0.4 & 0.5 & 0.3 \\
\hline
\end{tabular}

$\mu \mathrm{m}$ thick, and unlike other regions of the exoskeleton (Menzel et al, 1969), remains this size. Its basic ultrastructure has already been described (Locke, 1961; Hep- burn, 1986) and these details have been reconfirmed in this study. The epidermis lacks both dermal glands (Schnelle, 1923) and, more importantly, smooth endoplas-

Table VII. Average composition (percentage) of hydrocarbons in wax gland tissues and waxes of the Cape honeybee.

\begin{tabular}{lrrrr}
\hline Hydrocarbon & Oenocytes & Epidermis & Scale wax & Comb wax \\
\hline $25: 0$ & 26.6 & 22.2 & 11.4 & 6.6 \\
$27: 0$ & 41.5 & 37.2 & 39.8 & 33.3 \\
$29: 0$ & 7.0 & 9.0 & 8.1 & 13.8 \\
$31: 0$ & 2.8 & 3.5 & 4.1 & 8.9 \\
$33: 0$ & 4.6 & 12.9 & 14.6 & 15.4 \\
$35: 0$ & 1.6 & 2.8 & 3.3 & 3.3 \\
Total & 84.3 & 87.6 & 81.3 & 81.3 \\
$31: 1$ & 5.4 & $-\overline{2}$ & $-\overline{5}$ & - \\
$33: 1$ & 10.3 & 4.2 & 4.9 & 6.5 \\
$35: 1$ & 0.0 & 8.2 & 13.8 & 12.2 \\
Total & 15.7 & 12.4 & 18.7 & 18.7 \\
\hline
\end{tabular}


Table VIll. Average composition (percentage) of fatty acids in wax gland tissues and waxes of the Cape honeybee.

\begin{tabular}{lrrrr}
\hline Fatty acid & Oenocytes & Epidermis & Scale wax & Comb wax \\
\hline & & & & \\
$12: 0$ & 6.6 & 2.7 & - & - \\
$14: 0$ & 3.8 & 25.4 & 15.3 & 4.7 \\
$16: 0$ & 14.1 & 5.7 & 4.9 & 20.2 \\
$18: 0$ & 4.5 & 0.3 & 1.8 & 1.4 \\
$20: 0$ & 1.9 & 0.5 & 5.0 & 1.8 \\
$22: 0$ & 1.6 & 23.7 & 28.3 & 3.3 \\
$24: 0$ & 47.8 & - & 3.0 & 35.8 \\
$26: 0$ & - & 58.4 & 1.9 & 2.9 \\
$28: 0$ & -5.8 & 68.4 & 72.1 \\
Total & 80.3 & 8.4 & 18.9 & 1.9 \\
$16: 1 \mathrm{n} 9$ & 3.5 & 2.6 & - & 15.0 \\
$18: 1 \mathrm{n} 9$ & 4.9 & 13.1 & 19.1 & - \\
$20: 1 \mathrm{n} 9$ & 1.3 & 19.1 & 7.2 & 16.9 \\
Total & 9.7 & 0.4 & 3.5 & 6.9 \\
$18: 2 \mathrm{n} 6$ & 6.7 & 8.4 & - & 2.0 \\
$18: 3 \mathrm{n} 6$ & 1.5 & 28.1 & 10.7 & - \\
$20: 4 \mathrm{n} 6$ & 1.1 & 0.4 & 1.8 & 8.9 \\
Total & 9.3 & - & - & 2.1 \\
$18: 3 \mathrm{n} 3$ & 1.2 & 0.4 & 1.8 & - \\
$20: 5 \mathrm{n} 3$ & 0.4 & & & 2.1 \\
Total & 1.6 & & & \\
\hline
\end{tabular}

mic reticulum (SER). The latter is absent during peak wax secretion (Sanford and Dietz, 1976) and, in fact, from the entire post-ecdysial life of the worker bee. The idea that the epidermis has no role in the actual synthesis of beeswax is not new (Holz, 1878). Indeed, it is now a general principle that SER is essential to lipid biosynthesis in insects (Dean et al, 1985; Keeley, 1985; Sedlak, 1985) and other animals (Alberts et al, 1983; Hall, 1984). The major role of the epidermis in the production of wax appears to be the development of an elaborate system of small transport tubules (Reimann, 1952; Locke, 1961; Hepburn, 1986).

The most notable and dynamic feature of the oenocyte is the abundant SER whose rise and fall are synchronized with measured periods of secretion (figure 8;
Hepburn and Muller, 1988), and which is considered to be indispensable for lipogenesis. On the other hand, the adipocyte is the primary site of intermediary metabolism in insects (Downer, 1985; Keeley, 1985), and the large quantities of lipid, protein and glycogen in the adipocytes associated with the wax gland support this generalization. The early mobilization of lipid from the adipocyte (table II) suggests that it might produce beeswax precursors. However, the absence of communicating junctions between adipocytes and oenocytes, and the fact that adipocyte lipid reserves are depleted prior to both the maximal development of the oenocyte SER and wax production mitigate against this possibility. Likewise, at maximal wax production the lipid content of the adipocyte is more or less constant. Finally, paraffins are synthe- 
sized by oenocytes and triglycerides by the adipocytes of locusts (Diehl, 1973), and in beetles, lipid oxidation proceeds in oenocytes after they have taken up lipid droplets through the PMRS from adipocytes (Romer et al, 1974). Collectively these observations do not support an adipocyte origin for beeswax lipids.

Although the fine structure of the wax mirror cuticle and its wax transport tubules have now been visualized (cf Hepburn, 1986) there remains the problem of the physical transport of beeswax precursors, a precise answer to which eludes us. However, Kurstjens et al (1990) recently reported a partial characterisation of the proteins of beeswax scales and comb in which some 17 fractions were separated. Two of these fractions have been implicated in wax precursor transport on the grounds that their molecular weight distributions closely approximate those of known honeybee apolipophorins. Thus it was suggested that hydrocarbons and fatty acid precursors of beeswax might be synthesized in the oenocytes (now strongly supported in the present work) and then transported through the haemolymph to the surface of the insect in the form of primary or modified apolipophorins (Kurstjens et al, 1990).

Before comparing the chemical content of the wax gland tissues with that of scale wax, it is important to note that the hydrocarbon and fatty acid content of the $A m$ capensis comb wax (tables VII and VIII) are virtually identical to those of its sister race, $A m$ scutellata reported by Tulloch (1980); results which lend confidence to the analysis presented here. The nature and origins of the large differences between scale and comb wax (tables VII and VIII) are post-secretory phenomena and have been treated in detail elsewhere (Kurstjens et al, 1985; Davidson and Hepburn, 1986; Hepburn and Kurstjens, 1988).
The general trends in the hydrocarbon profiles of the oenocytes include an agerelated increase in the saturated components (table III) reflecting considerable synthetic activity. By comparison, the epidermal hydrocarbons show more modest changes in relation to the ages of the bees (table IV); these are pronounced among the more minor groups, the unsaturated compounds. We believe that the hydrocarbons of the epidermis reflect oenocytederived material in transit because the epidermis lacks SER and its age-related changes in hydrocarbons are not synchronized with the cycle of secretion. There is an apparent discrepancy between the high $\mathrm{C}_{25}$ and low $\mathrm{C}_{35}$ content of the oenocytes vis-à-vis wax scales; but it could be that $\mathrm{C}_{33}$ is formed from $\mathrm{C}_{25}$ and $\mathrm{C}_{27}$ outside of the oenocytes.

The fatty acid profiles of the epidermal cells lacked evident patterns of change consistent with the ageing of the bees or with the cycle of wax synthesis and secretion (table $\mathrm{VI}$ - excepting $\mathrm{C}_{18}$ ). By contrast, large differences among the fatty acid pools of the oenocytes relate both to the ages of the bees and to the cycle of synthesis (table V) and secretion (fig 8). Likewise, the 'average' composition for fatty acids in oenocytes more closely mirrors scale wax composition than does that of the epidermis (table VIII). The presence of and increase of $\mathrm{C}_{12}$ in the oenocytes coupled to its absence from epidermis and scale wax (tables V, VI and VIII) further suggests that the oenocytes perform chain elongation reactions. The decrease in $\mathrm{C}_{16}$ and $\mathrm{C}_{24}$ over time in the oenocytes is also consistent with synthesis and subsequent export.

\section{CONCLUSIONS}

Both epidermal cells and adipocytes lack SER, an organelle essential to lipogenesis 
in insects, from emergence of the adult, through the cycle of wax synthesis and secretion and on to foraging behavior. The oenocytes are the only cells of the wax gland complex with SER and whose developmental fate closely matches periods of wax synthesis (tables I and II; fig 8). Unlike those of the epidermis, the hydrocarbon and fatty acid profiles of isolated oenocytes share much in common with newly synthesized scale wax. That the oenocytes are the probable source of beeswax hydrocarbons is supported by the close cyclical changes in ultrastructure that coincide with age-related cycles of secretion of beeswax by worker honeybees. These interpretations are consistent with the histochemical data of Reimann (1952), the autoradiographic studies of Piek (1964) and studies of hydrocarbon synthesis in other insects by Diehl $(1973,1975)$.

\section{Résumé - Synthèse et sécrétion de la cire chez l'abeille (Apis mellifera $\mathrm{L}$ ). L'étude a porté sur : \\ - les modifications ultrastructurales des or- ganites des glandes cirières; \\ - les modifications des spectres d'hydro- carbures et d'acides gras des cellules des glandes cirières et de la cire et \\ - la secrétion réelle de la cire en fonction de l'âge des ouvrières.}

II n'existe pas de reticulum endoplasmique lisse, organite essentiel à la synthèse des lipides, dans l'épiderme, ni dans les adipocytes des glandes cirières chez les ouvrières adultes. Néanmoins, les oenocytes sont extrêmement riches en reticulum endoplasmique lisse et le développement dans le temps de cet organite suit étroitement celui de la sécrétion cirière. La fonction primaire de l'épiderme dans la sécrétion cirière est l'élaboration des canalicules pour le transport de la cire. Les adi- pocytes semblent servir de source d'énergie pour la synthèse et la secrétion.

Les fractions hydrocarbure et acide gras des adipocytes et des oenocytes ont été analysées en fonction de l'âge des abeilles. La composition et le rapport des 2 groupes de composés suivent étroitement ceux de la cire fraîchement secrétée. II semble que les oenocytes soient le siège primaire de la synthèse des hydrocarbures et des acides gras de la cire et que ces précurseurs de la cire soient transportés par des lipophorines à travers l'épiderme jusqu'à la surface de la cuticule des miroirs à cire. Les grandes différences de composition chimique entre la cire fraîchement secrétée et la cire des rayons sont des phénomènes postérieurs associés à la malaxation de la cire pendant la construction.

On a déterminé la quantité de cire produite par les abeilles en fonction de leur âge et les résultats montrent qu'elle y est significativement liée. La courbe caractéristique de la sécrétion cirière suit étroitement celle des changements de l'ultrastructure et de l'histologie des glandes cirières. Parmi tous les tissus des glandes cirières de l'abeille, seuls les oenocytes présentent les caractères nécessaires, dans leur ultrastructure et leurs modifications temporelles, pour être le siège de la secrétion des hydrocarbures et des acides gras de la cire.

cire / secrétion / synthèse / glande cirière / ultrastructure / composition chimique

Zusammenfassung - Synthese und Abscheidung von Wachs bei den Honigbienen. Es wurden die Veränderungen der Ultrastruktur der Organellen in den wachsabsondernden Zellen, Veränderungen in den Kohlenwasserstoff- und Fettsäure- 
Profilen der Wachsdrüsenzellen, des Wachses und des umittelbar abgesonderten Wachses in Bezug auf das Alter der Honigbienen bestimmt. Ein endoplasmatisches Retikulum, die für die Lipidsynthese entscheidende Organelle, kommt weder in der Epidermis noch in den Adipozyten des Wachsdrüsenkomplexes der adulten Arbeitsbiene vor. Es sind jedoch die Oenozyten extrem reich an endoplasmatischem Retikulum und die Entwicklung dieser Organelle über die Zeit stimmt sehr gut mit der Wachsabscheidung überein. Die primäre Funktion der Epidermis für die Wachsabscheidung ist die Ausbildung der Kanälchen für den Wachstransport. Die Adipozyten scheinen als Energiequelle für die Synthese und Absonderung zu dienen.

Die Kohlenwasserstoff- und Fettsäurefraktion der Adipozyten und Oenozyten wurden in Bezug auf das Alter der Bienen analysiert. In Zusammensetzung und dem Verhältnis der beiden Stoffgruppen besteht eine große Überreinstimmung mit frisch abgesondertem Bienenwachs. Es scheint so zu sein, daß die Oenozyten die primäre Synthese-Stelle der Kohlenwasserstoff- und Fettsäure-Anteile am Bienenwachs sind und daB diese WachsVorstufen durch die Epidermis zur Oberfläche der Wachsspiegel transportiert werden. Bedeutende chemische Unterschiede zwischen frisch abgesondertem Bienenwachs und dem Wachs der Waben sind nachträgliche Erscheinungen, die als Folge der Bearbeitung des Wachses während des Bauens auftreten.

Es wurde die Wachsmenge bestimmt, die von Bienen verschiedenen Alters produziert wird, und es konnte gezeigt werden, daß eine signifikante Altersabhängigkeit besteht. Die charakteristische Kurve der Wachsabscheidung in Bezug auf das Bienenalter stimmt sehr eng mit den histologischen und Ultra-
struktur-Veränderungen des Wachsdrüsenkomplexes überein. Von allen Gewebebestandteilen des Wachsdrüsenkomplexes der Arbeitsbienen zeigen nur die Oenozyten die Ausstattung in ihrer Ultrastruktur und ihren zeitlichen Veränderungen die nötigen Voraussetzungen als Sekretionsquelle für die Kohlenwasserstoff- und Fettsäureanteile des Bienenwachses.

Wachsabscheidung / Wachssynthese /
Wachsdrüse / Ultrastruktur / chemi-
sche Zusammensetzung

\section{REFERENCES}

Alberts B, Bray D, Lewis J, Raff M, Roberts K, Watson JD (1983) Molecular Biology of the Cell. Garland, NY

Blomquist GJ, Ries MK (1979) The enzymatic synthesis of wax esters by a microsomal preparation from the honeybee, Apis mellifera L. Insect Biochem 9, 183-188

Boehm B (1965) Beziehungen zwischen Fettkörper, Oenocyten und Wachsdrüsentwicklung bei Apis mellifica L. Z Zellforsch Mikrosk Anat 65, 74-115

Davidson BC, Hepburn HR (1986) Transformations of the acylglycerols in comb construction by honeybees. Naturwissenschaften 159, 73-74

Dean RL, Locke M, Collins JV (1985) Structure of the fat body. In: Comprehensive Insect Physiology, Biochemistry and Pharmacology (Kerkut GA, Gilbert LI, eds) Pergamon, Oxford, vol 3

Diehl PA (1973) Paraffin synthesis in the oenocytes of the desert locust. Nature (Lond) 243, 468-470

Diehl PA (1975) Synthesis and release of hydrocarbons by the oenocytes of the desert locust, Schistocerca gregaria. J Insect Physiol 21, 1237-1246

Downer RGH (1985) Lipid metabolism. In: Comprehensive Insect Physiology, Biochemistry 
and Pharmacology (Kerkut GA, Gilbert LI, eds) Pergamon, Oxford, vol 10

Dumas JB, Edwards HM (1843) Remarques sur la production de la cire. Ann Sci Nat (Paris) $20,1-8$

Folch J, Lees M, Sloane-Stanley GM (1957) A simple method for the isolation and purification of total lipids from animal tissues. $J$ Biol Chem 226, 497-501

Freudenstein H (1960) Einfluss der Pollennahrung auf des Bauvermögen, die Wachsdrüsen und den Fettkörper der Honigbiene (Apis mellifera L). Zool Jahrb Allg Zool Physiol Tiere 69, 95-124

Hall PF (1984) Cellular organization for steroidogenesis. Int Rev Cytol 86, 53-95

Hepburn HR (1986) Honeybees and Wax. Springer, Heidelberg

Hepburn HR, Kurstjens SP (1988) The combs of honeybees as composite materials. Apidologie 19, 25-36

Hepburn HR, Muller WJ (1988) Wax secretion in honeybees. Thermal integrity of the festoon. Naturwissenschaften 75, 628-629

Hepburn HR, Hugo JJ, Mitchel D, Nijland MJM, Scrimgeor (1984) On the energetic costs of wax production by the African honeybee, Apis mellifera adansonii. $S$ Afr $J$ Sci 80, 363368

Holz H (1978) Das Organ der Wachsbildung. Bienen-Ztg 34, 183-184

Keeley IL (1985) Physiology and biochemistry of the fat body. In: Comprehensive Insect Physiology, Biochemistry and Pharmacology (Kerkut GA, Gilbert LI, eds) Pergamon, Oxford, vol 3

Kurstjens SP, McClain E, Hepburn HR (1990) The proteins of beeswax. Naturwissenschatten 77, 34-35

Kurstjens SP, Hepburn HR, Schoening FRL, Davidson BC (1985) The conversion of wax scales into comb wax by African honeybees. J Comp Physiol B156, 95-102

Lambremont EM, Wykle RL (1979) Wax synthesis by an enzyme system from the honey bee. Comp Biochem Physiol 63B, 131-135

Locke $M$ (1961) Pore canals and related structures in insect cuticle. J Biophys Biochem $\mathrm{Cy}$ tol 10, 589-618
Locke M, Huie F (1980) Ultrastructure methods in cuticle research. In: Cuticle Techniques in Arthropods (Miller TA, ed) Springer-Verlag, Berlin

Menzel R, Wladarz G, Lindauer M (1969) Tagesperiodisches Ablagerungen in der Endokutikula der Honigbiene. Biol Zentrab/ 88, 6167

Miller T, James J (1976) Chemical sensitivity of the hyperneural nerve muscle preparation of the American cockroach. J Insect Physiol 22, 981-988

Moscatelli EA (1972) Methanolysis of cerebrosides with boron trifluoride-methanol. Lipids 7, 268-271

Piek T (1961) Synthesis of wax in the honey bee (Apis mellifera L) Proc K Ned Akad Wet Ser C Biol Med Sc 64, 648-654

Piek T (1964) Synthesis of wax in the honeybee (Apis mellifera L). $J$ Insect Physiol 10, 563572

Reimann K (1952) Neue Untersuchungen über die Wachsdrüse der Honigbiene. Zool Jahrb Abt Anat Ont 72, 147-188

Reynolds ES (1963) The use of lead citrate of high $\mathrm{pH}$ as an electron-opaque stain in electron microscopy. J Cell Biol 17, 208

Ribbands CR (1953) The Behaviour and Social Life of Honeybees. Bee Research Association, London

Romer F, Emmerich H, Nowock J (1974) Biosynthesis of ecdysones in isolated prothoracic glands and oenocytes of Tenebrio molitor in vitro. J Insect Physiol 20, 1975-1987

Rösch GA (1927) Uber die Bautätigkeit im Bienenvolk und das Alter der Baubienen. Weiterer Beitrag sur Frage nach der Arbeitsteilung im Bienenstaat. Z Vgl Physiol 6, 265-298

Sanford MT, Dietz A (1976) The fine structure of the wax gland of the honeybee (Apis mellifera L). Apidologie 7, 197-207

Schnelle H (1923) Über den feineren Bau des Fettkorpers der Honigbiene. Zool Anz 57, 172-179

Sedlak BJ (1985) Structure of endocrine glands. In: Comprehensive Insect Physiology, Bio- 
chemistry and Pharmacology (Kerkut GA, Gilbert $\mathrm{Ll}$, eds), Pergamon, Oxford, vol 7

Tulloch AP (1980) Beeswax - composition and analysis. Bee World 61, 47-62

Watson ML (1958) Staining of tissue sections for electron microscopy with heavy metals. $J$ Biophys Biochem Cytol 4, 475-478
Weibel ER, Bolender RP (1973) Stereological techniques for electron microscopic morphometry. In: Principles and Techniques of Electron Microscopy: Vol 3, Biological Applications (Hayat MA, ed) Van NostrandReinhold, Princeton

Winston M (1987) The Biology of the Honey Bee. Harvard, Cambridge 